\title{
Energy Performance of Offices Buildings in Brazil using Insulated Glass Units
}

\author{
Mônica Martins Pinto ${ }^{1}$, Fernando Simon Westphal ${ }^{1}$ \\ Federal University of Santa Catarina, Florianópolis, Brazil
}

\begin{abstract}
The insulated glazing system is widely used in Europe and North America as a strategy to improve energy performance and thermal comfort in buildings. However, it has been introduced to the Brazilian market without considering the local climate, predominantly tropical. The proper choice of the glass is essential to reduce energy consumption as it is through the glass that the most direct and intense heat exchange occurs. This research aims to investigate the energy performance of office buildings in Brazil that have used insulated glass units (IGUs) on the facades. The energy's analyses were conducted through computer simulation through the software EnergyPlus. Different facades' configurations were tested using different combinations of Window-to-wall-ratio (WWR) and Solar Heat Gain Coefficient (SHGC). Building's models with IGUs showed an energy consumption for cooling up to $11 \%$ higher than models with laminated single-pane glass unit $\left(\mathrm{SGU}_{\mathrm{L}}\right)$ on temperate climate (southern Brazil). Modest values of energy savings, around $4 \%$, were verified for models with IGUs in warmer climates.
\end{abstract}

\section{Introduction}

Brazil presents a high level of electricity consumption, those numbers are continuously increasing, and the costs for electricity generation and consumption follows the same path, getting more expensive over time. In 2017, buildings' consumption accounted for $42.8 \%$ of total electricity generated in the country, being $14.4 \%$ the parcel used by the commercial sector, such as offices, shopping centers, schools and retails (MME, 2018). When considering the final use of energy in the commercial sector, studies show that air conditioning represents 35 to $70 \%$ of the total energy consumed by those buildings ( $\mathrm{Li}$; Lam, 2000; Carvalho; Rovere; Gonçalves, 2010; Besen; Westphal, 2014).

The building cooling load is composed of internal and external gains. Internal gains derive mainly from people, lighting and plug loads. External gains are usually a result of heat exchanges through the building envelope. This element should act as a moderator filter (of light, heat, air and moisture) between the indoor and the external environments. Therefore, it is a determining factor to maintain the indoor environmental quality and maximize the energy's efficiency of the building, regardless of variations in external conditions.
When focusing on the heat transfer through the envelope, the concern with glasses is emphasized. The exchanges are more direct and intense in those elements due to their transparency to solar radiation and high thermal transmittance. According to Lee et al. (2013), the thermal conductance of windows is usually five times higher than other components of the building envelope. Because of it, about 20 to $40 \%$ of the total energy consumed in the building is wasted through windows. The choice of glass in architectural design may be characterized as a passive cooling strategy when designed to soften the effect of solar radiation in hot climates. Singh and Garg (2009) highlighted the relationship between climate and energy savings. The same window will not work identically in a climate where heating is dominant and in another that requires a large amount of cooling along the year.

The use of the "international design" for buildings' design in Brazil, i.e., fully glazed facades, is applied not only to the architectural design itself but also to technologies used for the construction, not always considering the local climate. The insulated glass units (IGUs) are an example of this scenario. This type of arrangement comprises two or more glass layers positioned parallel with a low thermal conductivity gas chamber between them. The main intent of this configuration is the thermal insulation provided by the gas layer, usually air. This layer acts as a thermal insulation to conduct the heat flow between exterior and interior environment. It can be used as a strategy to increase the energy's efficiency in extremely cold climates as it makes difficult the loss of heat through the building envelope (Huang; Niu; Chung, 2014), thus, the IGU is widely used in Europe and North America.

Researches conducted in Europe and North America focuses on different configurations of insulated glass with one, two or three gas layers. Some examples are the studies developed by Stegou-Sagia et al. (2007), which considers Greek climates (Athens and Thessalonica); Poirazis, Blomsterberg and Wall (2008), applied for Gothenburg, Sweden; Jaber and Ajib (2011), conducted for Amman and Aqaba, Jordan, and Berlin, Germany; Ochoa et al. (2012), considered the climate of Amsterdam, Netherlands; Lee et al. (2013) analyzed Asian climates; and Atzeri et al. (2016), was applied for Rome, Italy.

The local's latitude is a determining factor to the amount of solar radiation incident at the building's facade. Tropical areas have less fluctuation in the solar radiation 
intensity and in the length of the days along the year when compared to regions in high latitude (Pillar, 1995). Brazil is located almost entirely in the intertropical region, while most countries in North America (United States, Canada, and Greenland) and Europe are located above the tropics, as seen in Figure 1.

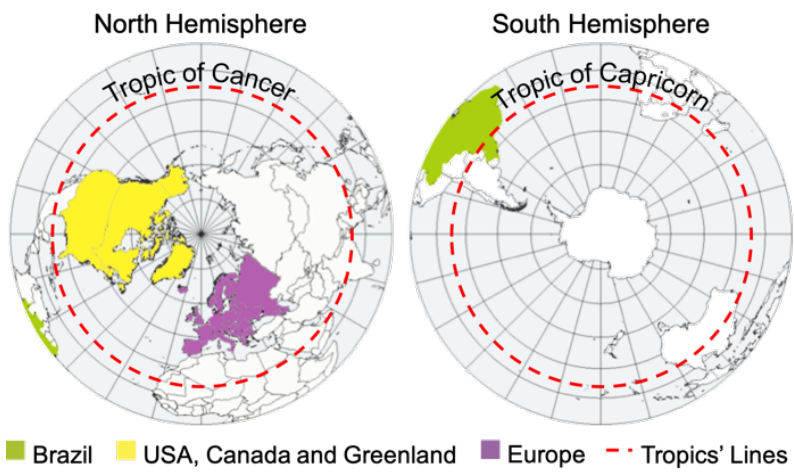

Figure 1: Map locating Brazil, North America and Europe in relation to the tropics

Because of Brazil's location, Brazilian climates tend to show a lower variation of temperatures and climatological conditions throughout the year. Otherwise, countries in North America and Europe tend to have more rigorous winters and higher thermal amplitude between seasons. Exemplifying these differences, Figure 2 shows the monthly average temperatures of two Brazilian cities, Florianópolis (southern region) and Boa Vista (northern region), compared to Athens, New York, and London.

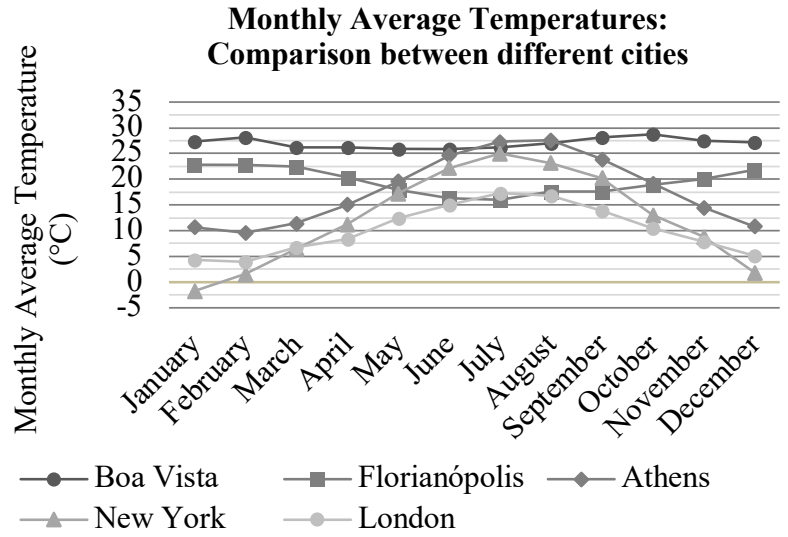

Figure 2: Comparison of monthly average temperatures between cities of Brazil, North America and Europe. Source of data: DOE, 2019.
Given the climate differences between Brazil and places of the previous studies mentioned above, the use of IGUs is questioned as energy efficiency and thermal comfort strategy for Brazilian office buildings.

Furthermore, implementation costs of using IGU instead of laminated single-pane glass unit $\left(\mathrm{SGU}_{\mathrm{L}}\right)$ tend to be $50 \%$ higher. It is consequence of the additional material used (both glass and frame material); and skilled labor needed for installation and maintenance.

The aim of this study is to analyze the thermal performance of an office building with IGU in the Brazilian climatic context. Energy consumption estimates for a typical office floor were obtained through computer simulation by using the software EnergyPlus. A typical floor of an open plan office was modeled with high internal loads density. Nine Brazilian cities were selected to cover a variety of climates along the country, mainly in relation to air temperature and solar radiation incidence.

\section{Methods}

This research was developed in five steps: (1) selection of climates; (2) definition of building model; (3) specification of variable parameters; (4) computer simulation; and (5) output data analysis.

\section{Selection of climates}

The incidence of solar radiation onto the building facade and the temperature difference between indoor and outdoor air are the main climatic factors that influence the thermal performance of building that has a fully glazed wall. Thus, Brazilian cities were selected to represent different climate scenarios. The criteria used were the annual average and variability of horizontal global solar radiation, annual average of air temperature and latitudinal distribution of cities, among state capitals. It was sought that this selection covers the Brazilian climatic variations.

The average of the solar radiation data was obtained from the Brazilian Atlas of Solar Energy (Pereira et al., 2006). The following maps were used for this research: Annual Average of Global Solar Horizontal Radiation and the four maps of Average Seasonal of Global Solar Radiation. The outdoor air temperature data from the weather files were used to obtain the average annual temperatures.

Based on this procedure, nine cities were selected, as presented in Table 1, with their climatic data summary.

Table 1: Data of global horizontal solar radiation and annual average air temperature of selected cities.

\begin{tabular}{|c|c|c|c|c|c|c|c|}
\hline \multirow[t]{2}{*}{ City } & \multirow[t]{2}{*}{ Latitude } & \multirow{2}{*}{$\begin{array}{c}\text { Average Annual } \\
\text { Radiation } \\
\left(\mathbf{k W h} / \mathbf{m}^{2}\right)\end{array}$} & \multicolumn{4}{|c|}{ Average Seasonal Radiation $\left(\mathrm{kWh} / \mathrm{m}^{2}\right)$} & \multirow{2}{*}{$\begin{array}{c}\text { Annual Average } \\
\text { Air Temperature } \\
\left({ }^{\circ} \mathrm{C}\right)\end{array}$} \\
\hline & & & Dec-Feb & Mar-May & Jun-Aug & Sep-Nov & \\
\hline Porto Alegre (RS) & $30.0 \mathrm{~S}$ & $4.55-4.90$ & $6.30-6.68$ & $3.85-4.20$ & $0-3.15$ & $5.25-5.60$ & 19.26 \\
\hline Florianópolis (SC) & $27.6 \mathrm{~S}$ & $4.20-4.55$ & $5.60-5.95$ & $3.85-4.20$ & $0-3.15$ & $4.55-4.90$ & 20.75 \\
\hline Curitiba (PR) & $25.4 \mathrm{~S}$ & $4.55-4.90$ & $5.60-5.95$ & $3.85-4.20$ & $3.15-3.50$ & $4.90-5.25$ & 17.19 \\
\hline Campo Grande (MS) & $20.4 \mathrm{~S}$ & $5.25-5.60$ & $5.95-6.30$ & $4.55-4.90$ & $4.20-4.55$ & $5.95-6.30$ & 24.04 \\
\hline Cuiabá (MT) & $15.6 \mathrm{~S}$ & $5.25-5.60$ & $5.60-5.95$ & $4.55-4.90$ & $4.55-4.90$ & $5.60-5.95$ & 26.73 \\
\hline Salvador (BA) & $13.0 \mathrm{~S}$ & $4.90-5.25$ & $5.95-6.30$ & $4.55-4.90$ & $3.85-4.20$ & $5.25-5.60$ & 25.96 \\
\hline Recife (PE) & $8.0 \mathrm{~S}$ & $4.90-5.25$ & $5.60-5.95$ & $4.55-4.90$ & $3.85-4.20$ & $5.25-5.60$ & 27.15 \\
\hline São Luís (MA) & $2.5 \mathrm{~S}$ & $5.25-5.60$ & $5.25-5.60$ & $4.55-4.90$ & $5.25-5.60$ & $5.60-5.95$ & 26.74 \\
\hline Boa Vista (RR) & $2.8 \mathrm{~N}$ & $5.25-5.60$ & $5.25-5.60$ & $4.90-5.25$ & $4.90-5.25$ & $5.60-5.95$ & 27.02 \\
\hline
\end{tabular}




\section{Building model}

This study analyzed a typical floor of a hypothetical openplan office building. The same building model used by Lam and Hui (1995) in their sensitivity analysis for Hong Kong was adopted and adapted for this research. It is a square plan, with simplified internal divisions.

The model was divided into nine thermal zones: four peripheral, four internal and a central core. External zones were defined as 4.57 meters wide, according to recommendations described in the Energy Cost Budget method in ASHRAE Standard 90.1 (ASHRAE, 2007). This configuration enables analysis related to solar orientation and to the areas closest to the windows that receive greater influence from the outdoor environment than the other areas. Figure 3 shows a schematic plan of the model and its dimensions and its thermal zoning.

Although the standard does not define how internal partitions must be set, it was configured as virtual partitions without physical walls between thermal zones, keeping open plan configuration. These boundaries were indicated in Figure 3 as dashed lines. The configuration of these partitions was modeled by EnergyPlus as an Infrared Transparent material. This partition configuration was chosen by reason of this material works as a transparent element that allows the transmission of visible and solar radiation but does not take part with convective and conductive heat exchanges between adjacent zones.
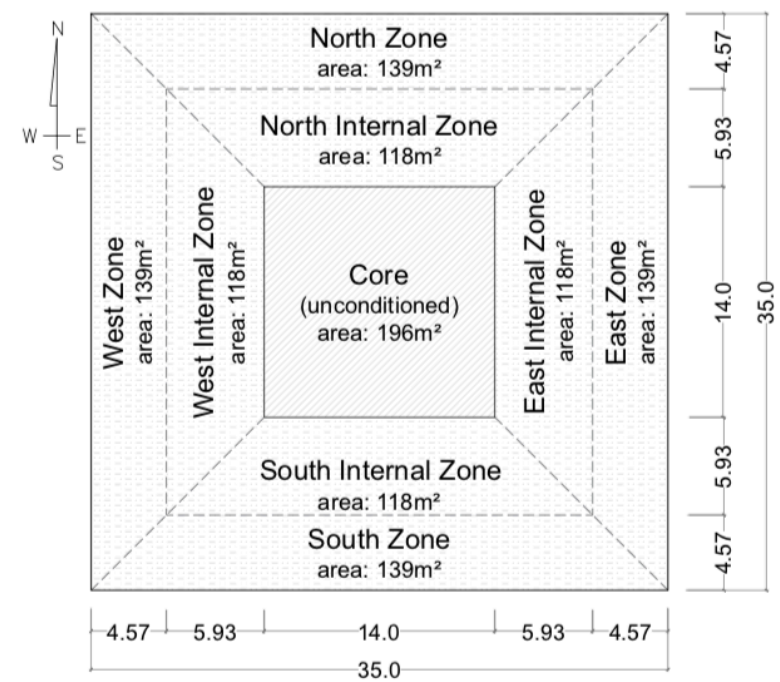

$\square$ Conditioned zone
$\square$ Unconditioned zone
-- Virtual partitions

Figure 3: Schematic plan of the typical floor and thermal zoning (unit: $m$ ).

Internal loads densities (people, lights and plug loads) were defined according to Brazilian standard for HVAC sizing and design (ABNT, 2008) for offices with high occupancy density. Metabolic rate for each person was established according to Annex B of ISO 7730: 2005 (ISO, 2005). Table 2 shows the internal loads densities assumed for the building model.
Table 2: Summary of internal loads densities

\begin{tabular}{|cccc|}
\hline People & Equipment & Light & Metabolic Rate \\
\hline $7.7 \mathrm{~m}^{2} /$ person & $21.5 \mathrm{~W} / \mathrm{m}^{2}$ & $16.0 \mathrm{~W} / \mathrm{m}^{2}$ & $126 \mathrm{~W} /$ person \\
\hline
\end{tabular}

Schedules of use and occupancy have been configured as shown in Figure 4. Occupancy and systems are reduced between 12 and 15 hours for the lunch period. There is no activity in the building during the weekend. It was determined that $5 \%$ of the lighting and plug loads remain switched on during the periods without occupancy. The activation of the artificial lighting has been configured statically, regardless the daylighting availability.

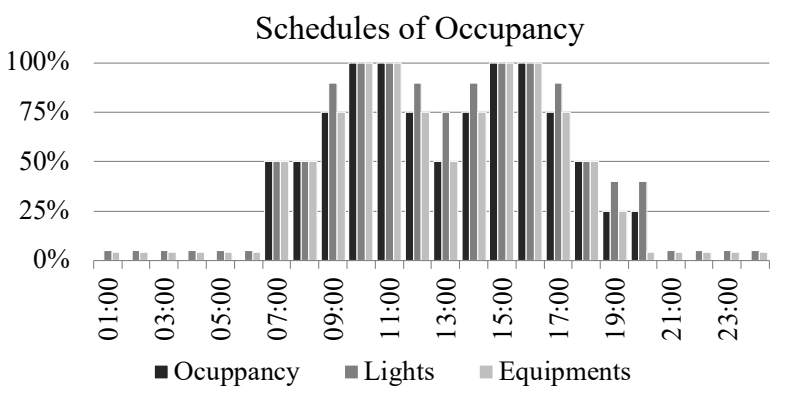

Figure 4: Schedules of occupancy for weekdays

The building is artificially conditioned with PTHP (Packaged Terminal Heat Pump), except the core which is unconditioned. Table 3 summarizes the characteristics and settings of the HVAC system. The system is available to operate from 7 am to $9 \mathrm{pm}$ in the weekdays. On weekends, the building was considered unoccupied and consequently without HVAC operation.

Table 3: Air conditioning system characteristics

\begin{tabular}{|cc|}
\hline System & PTHP (Packaged Terminal Heat Pump) \\
\hline COP & $3.0 \mathrm{~W} / \mathrm{W}$ \\
\hline Capacity & Autosized by EnergyPlus \\
\hline Outdoor air & $0.0075 \mathrm{~m}^{3} / \mathrm{s}$ per person \\
\hline Thermostat & Heating: $20^{\circ} \mathrm{C}$ \\
Set points & Cooling: $24^{\circ} \mathrm{C}$ \\
\hline
\end{tabular}

Table 4 shows the thermal transmittance (U-value) and solar absorptance of opaque envelope compositions. The constructions were selected based on the Brazilian regulation (INMETRO, 2013) for level A of energy efficiency for buildings.

Exterior walls were covered with the same $\mathrm{SGU}_{\mathrm{L}}$ used in the windows. This condition was included in the simulation models as a transparent insulating material of EnergyPlus. The input object used was "SurfaceControl: MovableInsulation". This object provides insulation to heat loss without reducing drastically the transmittance of solar energy.

Roller blinds with medium reflectance and low transmittance were used inside all fenestrations. These shading devices were configured to be closed when the solar radiation incident on windows exceeds $250 \mathrm{~W} / \mathrm{m}^{2}$.

The building model was configured as an intermediate floor, on the tenth floor (30 meters high). Thus, roof and floor were configured as adiabatic surfaces. 
Table 4: Thermal properties of materials

\begin{tabular}{|c|c|c|c|}
\hline Composition & $\begin{array}{c}\text { U-Value } \\
\left(\mathbf{W} / \mathbf{m}^{2} \cdot \mathbf{K}\right)\end{array}$ & $\begin{array}{c}\text { Solar } \\
\text { Absor. }\end{array}$ & $\begin{array}{c}\text { Heat } \\
\text { Capacity } \\
\left(\mathbf{k J} / \mathrm{m}^{2} . \mathbf{K}\right)\end{array}$ \\
\hline \multicolumn{4}{|l|}{ Exterior Walls } \\
\hline $\begin{array}{c}\text { Plasterboard }(12.5 \mathrm{~mm})+ \\
\text { Glass wool }(50 \mathrm{~mm})+ \\
\text { Cement board }(10 \mathrm{~mm})\end{array}$ & 0.77 & \begin{tabular}{|c|} 
Indoor: \\
0.297 \\
Outdoor: \\
0.297
\end{tabular} & 24.31 \\
\hline \multicolumn{4}{|c|}{ Interior Walls (around the core zone only) } \\
\hline $\begin{array}{c}\text { Plasterboard }(15 \mathrm{~mm})+\text { Glass } \\
\text { wool }(50 \mathrm{~mm})+\text { Plasterboard } \\
(15 \mathrm{~mm})\end{array}$ & 0.69 & 0.297 & 25.55 \\
\hline \multicolumn{4}{|l|}{ Ceiling } \\
\hline Plasterboard $(15 \mathrm{~mm})$ & 1.40 & 0.297 & 11.03 \\
\hline \multicolumn{4}{|l|}{ Slab } \\
\hline $\begin{array}{c}\text { Mortar }(25 \mathrm{~mm})+ \\
\text { Concrete slab }(200 \mathrm{~mm})+ \\
\text { Mortar }(25 \mathrm{~mm})+ \\
\text { Ceramic floor }(7.5 \mathrm{~mm})\end{array}$ & 2.74 & $\begin{array}{c}\text { Grout: } \\
\alpha=0.297 \\
\text { Floor: } \\
\alpha=0.418\end{array}$ & 551.04 \\
\hline
\end{tabular}

\section{Specification of Variables Parameters}

In order to verify the effects of increasing windows' thermal insulation on buildings' performance, comparisons between IGUs (double glass layers with an air gap) and $\mathrm{SGU}_{\mathrm{L} S}$ were performed. The insulated glass is composed of a laminated single-pane glass unit, corresponding to a base SHGC, plus a $12.7 \mathrm{~mm}$ thick air gap and a clear monolithic $6 \mathrm{~mm}$ glass layer. It is assumed that SHGC base is the SHGC of laminated glass used in the comparative scenario of $\mathrm{SGU}_{\mathrm{L}}$ and its insulated composition. This assumption was made in order to isolate the effects of the increasing in thermal resistance of insulated glass generated by the air gap.
Below are described the parameters assumed for glass composition, SHGC and WWR:

a) Glass type: IGU versus $\mathrm{SGU}_{\mathrm{L}}$;

b) SHGC: 0.28, 0.40, 0.52 and 0.57;

c) WWR: $30 \%, 40 \%, 50 \%$ and $60 \%$.

The same WWR was modeled for all facades. The combination of those factors resulted in 32 models simulated for each city. The specification of glass was selected from products available in the Brazilian market. Table 5 summarizes the thermal properties of laminated single-pane glass unit and insulated glass units for each level of SHGC. Thermal properties for IGUs were calculated using the software WINDOW 7.4 (LBLN, 2016).

\section{Computer Simulation}

The simulations of buildings' energy performance were carried out by the software EnergyPlus. These simulations required weather files with extension *.epw (Energy Plus Weather File) that characterizes the climate conditions of a base year, from hourly data. The files used in this study were obtained from the available library at EnergyPlus website database.

\section{Analysis}

The performance of an office building according to the fenestration system was investigated based on the annual energy consumption for air conditioning, especially cooling, as this is the energy end use that is affected by facades modifications. These results were analyzed in two approaches.

First, relationships amongst different parameters were analyzed. Afterward it was verified the percentage difference of energy consumption for cooling between pairs of models (same WWR and SHGC) with insulated glass and laminated single-pane glass unit. The aim of this second analysis was to identify in which cities IGU has an advantage over the use of SGUL.

Table 5: Summary of optical and thermal properties of glass types

\begin{tabular}{|c|c|c|c|c|c|}
\hline \multirow{2}{*}{$\begin{array}{l}\text { SHGC } \\
\text { Basis }\end{array}$} & & \multirow{2}{*}{$\begin{array}{l}\text { Laminated Single- } \\
\text { pane Glass Unit }\end{array}$} & \multicolumn{3}{|c|}{ Insulated Glass Unit } \\
\hline & & & External & Internal & Composition \\
\hline \multirow{4}{*}{$\begin{array}{c}\text { SHGC } \\
0.28\end{array}$} & Thickness [mm] & 8 & 8 & 6 & $8+12.7+6$ \\
\hline & Manufacturing Process & Laminated clear & Laminated clear & Monolithic & Laminated + air gap + monolithic \\
\hline & $\mathrm{U}$ value $\left[\mathrm{W} / \mathrm{m}^{2} \mathrm{~K}\right]$ & 5.63 & 5.63 & 5.7 & 2.745 \\
\hline & SHGC & 0.28 & 0.28 & 0.84 & 0.23 \\
\hline \multirow{4}{*}{$\begin{array}{c}\text { SHGC } \\
0.40\end{array}$} & Thickness [mm] & 8 & 8 & 6 & $8+12.7+6$ \\
\hline & Manufacturing Process & Laminated clear & Laminated clear & Monolithic & Laminated + air gap + monolithic \\
\hline & U value $\left[\mathrm{W} / \mathrm{m}^{2} \mathrm{~K}\right]$ & 5.63 & 5.63 & 5.7 & 2.745 \\
\hline & SHGC & 0.40 & 0.40 & 0.84 & 0.34 \\
\hline \multirow{4}{*}{$\begin{array}{c}\text { SHGC } \\
0.52\end{array}$} & Thickness [mm] & 8.4 & 8.4 & 6 & $8+12.7+6$ \\
\hline & Manufacturing Process & Laminated clear & Laminated clear & Monolithic & Laminated + air gap + monolithic \\
\hline & $\mathrm{U}$ value $\left[\mathrm{W} / \mathrm{m}^{2} \mathrm{~K}\right]$ & 5.6 & 5.6 & 5.7 & 2.791 \\
\hline & SHGC & 0.52 & 0.52 & 0.84 & 0.49 \\
\hline \multirow{4}{*}{$\begin{array}{l}\text { SHGC } \\
0.57\end{array}$} & Thickness $[\mathrm{mm}]$ & 8 & 8 & 6 & $8+12.7+6$ \\
\hline & Manufacturing Process & Laminated clear & Laminated clear & Monolithic & Laminated + air gap + monolithic \\
\hline & $\mathrm{U}$ value $\left[\mathrm{W} / \mathrm{m}^{2} \mathrm{~K}\right]$ & 5.63 & 5.63 & 5.7 & 2.745 \\
\hline & SHGC & 0.57 & 0.57 & 0.84 & $\mathbf{0 . 5 0}$ \\
\hline
\end{tabular}




\section{ANNUAL COOLING CONSUMPTION}

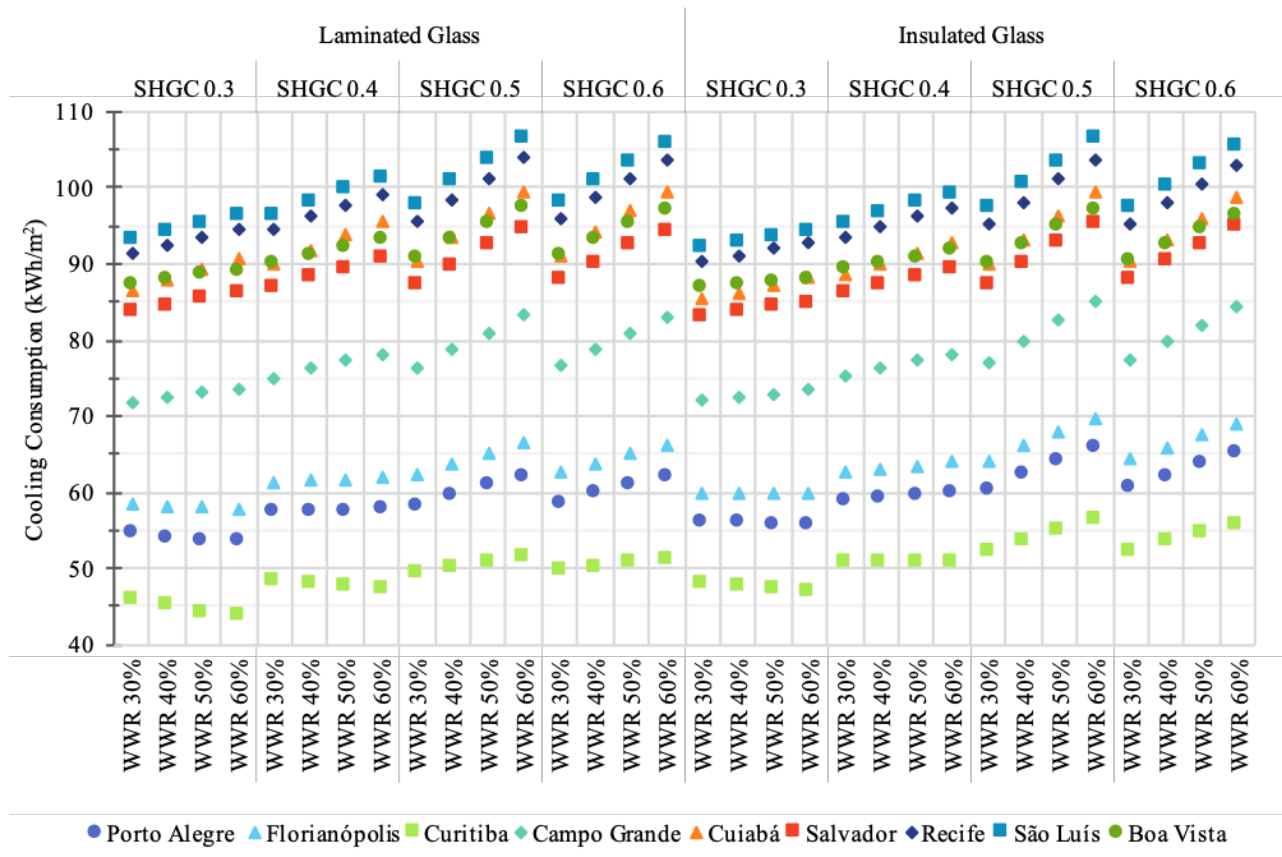

Figure 5: Annual electricity consumption for cooling

\section{Results and Discussion}

\section{Relation between variable parameters and energy consumption}

Relationships between distinct parameters (SHGC, WWR, and type of glass) and the energy consumption for cooling predicted for each city were analyzed. The data compilation output for all cities can be observed in Figure 5 .

Among the simulated models for Porto Alegre, Florianópolis and Curitiba, the use of the combination SGUL, SHGC 0.28 and WWR 60\% showed the lowest energy consumption. The highest energy consumption was verified for those models applying IGU, SHGC of 0.40 and 0.52 and WWR of $60 \%$. In those cities, the maximum difference in energy consumption for cooling between all cases per city achieved $28.2 \%$.

On the other hand, for Cuiabá, Recife, São Luís and Boa Vista the models that presented the lowest consumption for cooling were those using the combination IGU, SHGC 0.28 and WWR $30 \%$. For this group of cities, the models that presented the highest consumption were those with $\mathrm{SGU}_{\mathrm{L}}, \mathrm{SHGC}$ of 0.52 and 0.57 and WWR $60 \%$. The maximum difference in energy consumption for cooling between all cases per city was $16.6 \%$.

It is understood that the percentage amplitude consumption for cooling between models of the same city is higher in cities south of the country due to the fact that consumption is lower in these cities. In absolute terms, this variation is similar: 10,50 to $14,50 \mathrm{kWh} / \mathrm{m}^{2}$.

It is expected that the energy consumption for the models with the same glass increases as the WWR of the facade is increased. Nevertheless, the models showed that in cities with a mild climate (Porto Alegre, Curitiba, and
Florianópolis) there is no significant variation of energy consumption for cooling $\left(<1 \mathrm{kWh} / \mathrm{m}^{2}\right)$. Moreover, it was observed that in the scenarios with SGUL and SHGC 0.28 for Curitiba, the energy consumption for cooling reduced by up to $5 \%$ as the WWR increases, due to the increase in the heat loss through the facade.

The initial hypothesis applies integrally to building models simulated for Campo Grande, Cuiabá, Salvador, Recife, São Luís and Boa Vista (hottest climates). The energy consumption for cooling increases with the increase of WWR, especially for glazing with high SHGC.

Glazing systems with low SHGC have a better control over the solar radiation heat gain, therefore they reduce the building cooling needs. However, it is important to highlight that when the outdoor air temperature is lower than indoor air temperature, the heat loss through fenestration become effective, which can be beneficial to reduce cooling loads. Thus, increasing the WWR may not increase significantly the energy consumption in mild climates, mainly because each facade does not receive direct solar radiation during the whole day.

Although Porto Alegre, Florianópolis, and Curitiba presented average outdoor air temperatures below $20^{\circ} \mathrm{C}$ during winter, only a few models presented energy consumption for heating, due to the high level of internal loads densities. Even so, the values are negligible (below $0.001 \mathrm{kWh} / \mathrm{m}^{2}$ ). Another important observation is that, even in periods of time with low outdoor air temperature, the air conditioning system operates in cooling function to remove the heat gain generated from building internal sources. 


\section{Comparison among Insulated Glass Unit and Laminated Single-pane Glass Unit}

Figure 6 shows the differences in the energy consumption for cooling between models with IGU and SGUL, with same SHGC and WWR, as show in Equation (1).

$$
C C_{I G U-S G U L}=\frac{C C_{I G U}-C C_{S G U L}}{C C_{S G U L}} \times 100
$$

The difference is positive when the model with IGU has energy consumption higher than the model with SGUL. In opposition, the percentage is negative when the consumption with IGU is lower. A range of $+2 \%$ to $-2 \%$ was defined as an insignificant difference between models. This range would correspond to approximately one week of energy consumption of the building.

For Porto Alegre, Curitiba and Florianópolis, all models with IGU had presented higher annual energy consumption for cooling than models with SGUL (assuming the same SHGC and WWR combination). Curitiba showed the largest differences, $4.5 \%$ (SHGC 0.40 and WWR 30\%) and 9.3\% (SHGC 0.52 and WWR $60 \%$ ). This difference increases with the WWR.

On the other hand, for Cuiabá, Salvador, Recife, São Luís and Boa Vista the models with IGU presented lower energy consumption for cooling when compared to models with SGUL. However, these differences of consumption for cooling were significantly lower than those found for the group of cities mentioned above. For Salvador, Recife and Boa Vista, the energy savings differences were below $2 \%$. For Cuiabá, models with low SHGC and WWR between 40 and $60 \%$, presented over $2 \%$ of energy savings when utilizing IGU. São Luís presented only a situation like this, in the model with SHGC 0.28 and WWR 60\%. However, no model presented energy savings greater than 2.8\% (Cuiabá; SHGC 0.28; WWR 60\%) using the IGU.

Results indicate a clear division between the south and other regions of Brazil. In the southern region which has a temperate climate, models simulated with IGU show significantly higher consumption than models with SGUL. In contrast, cities with latitudes lower than $20^{\circ}$ (from Campo Grande to the north), models assuming IGU and $\mathrm{SGU}_{\mathrm{L}}$ presented predominantly equivalent energy consumption (differences less than $2 \%$ ).

Figure 7 illustrates this behavior. In the southern region (in green) the IGU did not present positive results. The results for the central area (in yellow) presented equivalence when using IGU and SGUL. In the northern zone (in blue), the choice between insulated glass unit or laminated single-pane glass unit shows no significant difference, but insulated glass tends to have slightly superior thermal performance. This infographic could be used as a basis to choose between the use or not of IGU by the designer of an office building in Brazil.

Figure 8 illustrates average daily temperatures throughout the year for all cities, highlighting the data for Porto Alegre, Curitiba, and Florianópolis. Dashed lines show the heating and cooling thermostat set points.

Based on the results presented, it is understood that, in locations with temperatures predominantly below the cooling set point, $\mathrm{SGU}_{\mathrm{L}}$ provides useful heat dissipation through the facade. In this situation, when is used IGU, the increase in thermal resistance generated by air gap hamper the heat dissipation to the colder exterior environment.

On the other hand, with daily average temperatures remaining above the cooling set point, the heat flow reverses and external heat is transferred into the building, which further raise the internal heat load and overloading the air conditioning system. In this case, the use of IGU avoids heat gain through conduction from the outdoor.

When the outside air temperature come close to the internal temperature maintained by the air conditioning system, the thermal transmittance of the glass has no significant influence on the thermal performance of the building.

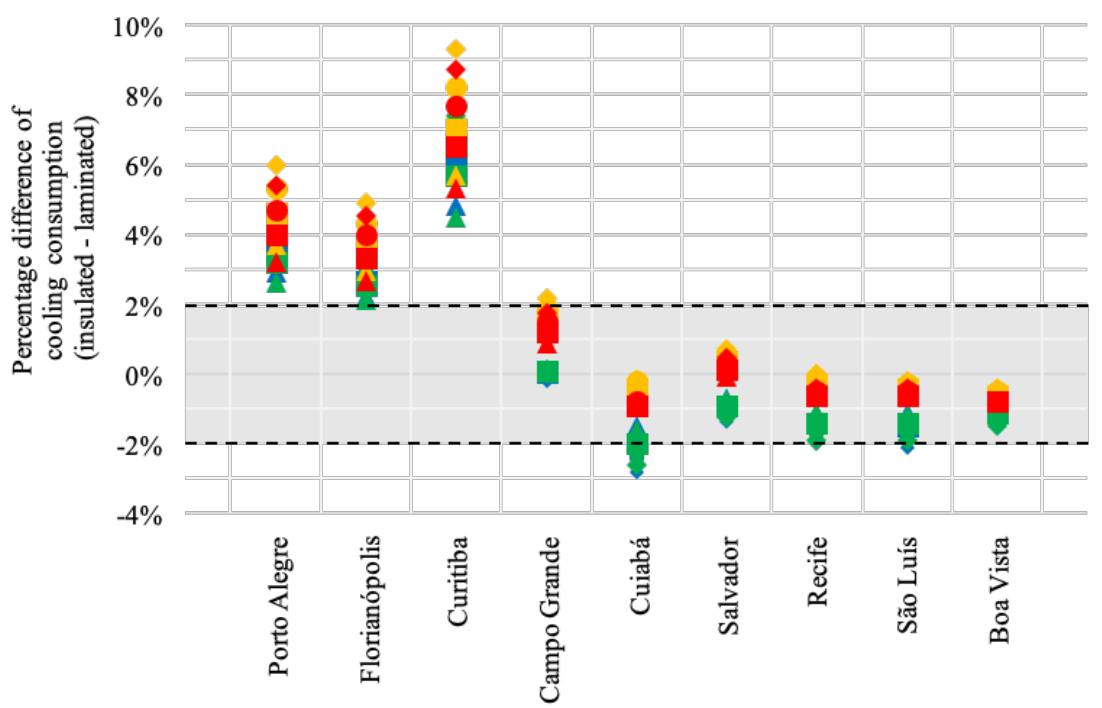

$\triangle$ SHGC 0.3 - WWR $30 \%$

SHGC 0.3 - WWR 40\%

- SHGC 0.3 - WWR 50\%

- SHGC 0.3 - WWR $60 \%$

$\triangle$ SHGC 0.4 - WWR 30\%

SHGC 0.4 - WWR $40 \%$

- SHGC 0.4 - WWR 50\%

- SHGC 0.4 - WWR 60\%

$\triangle$ SHGC 0.5 - WWR $30 \%$

SHGC 0.5 - WWR $40 \%$

SHGC 0.5 - WWR 50\%

SHGC 0.5 - WWR $60 \%$

$\triangle$ SHGC 0.6 - WWR 30\%

- SHGC 0.6 - WWR $40 \%$

- SHGC 0.6 - WWR 50\%

- SHGC 0.6 - WWR $60 \%$

Figure 6: Percentage difference of cooling consumption among models with insulated glass unit and models with laminated single-pane glass unit. 


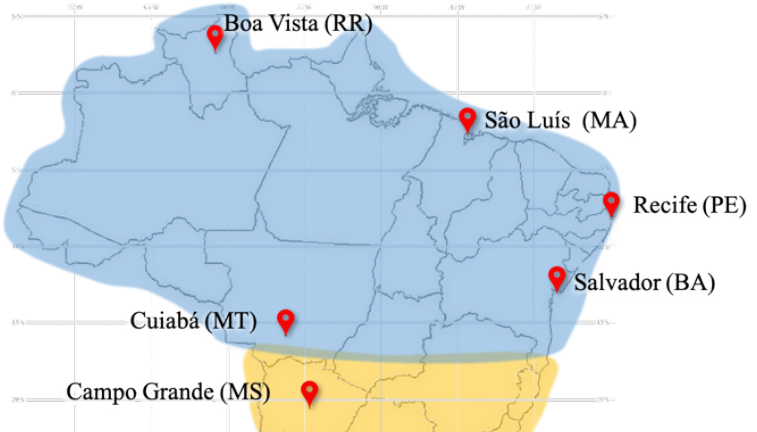

Curitiba (PR)

Florianópolis (SC)

Porto Alegre (RS)

Equivalence between glasses; with situations in which insulated glass performs better. Equivalent in energy performance between the use of insulated and laminated glass.

Insulated glass does not have good performance.

Figure 7: Demonstrative map of consumption results

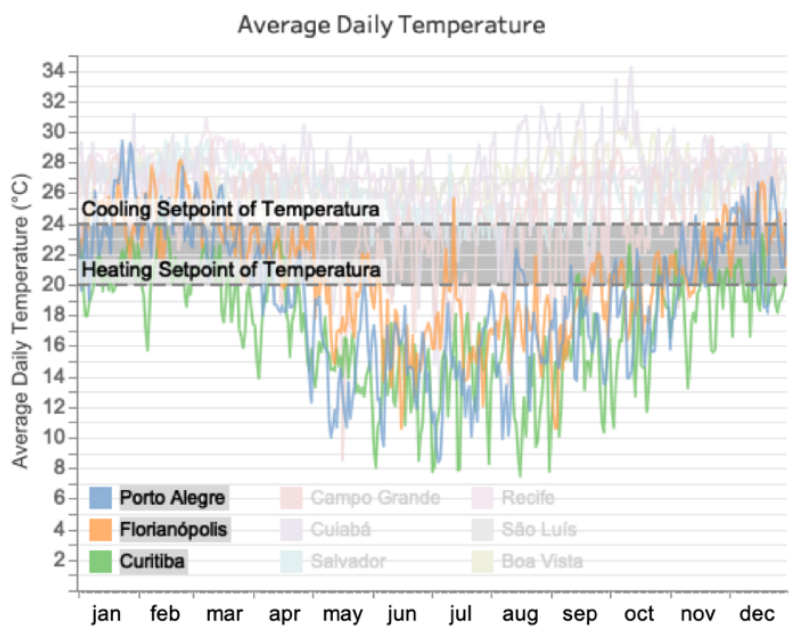

Figure 8: External air temperature - monthly averages

\section{Conclusion}

This study analyzed the use of IGUs in an office building in Brazil and the impact on energy consumption for cooling.

Relationships between SHGC, WWR, and type of window were analyzed. It was concluded that in cities with a temperate climate the influence of variations in building fenestrations tends to be higher than in cities with higher temperatures and incident solar radiation. This is the case of Porto Alegre, Florianópolis and Curitiba, which have a lower annual average air temperature and solar radiation incidence.

It was expected that the energy consumption of the models increases when the WWR rises. However, in mild climates (Porto Alegre, Florianópolis, and Curitiba), there is no significant variation in energy consumption for cooling between different WWR when using low SHGC glass $(0.28$ and 0.40$)$. In contrast, for cities with higher temperatures, such as Campo Grande, Cuiabá, Salvador, Recife, São Luís and Boa Vista, the initial hypothesis is applied. In addition, it has been confirmed that the lower the SHGC of the glass, the lower the influence of the WWR on the consumption for cooling.

Based on the results of energy consumption for cooling, the use of IGU in office buildings with the characteristics studied here in southern Brazil (temperate climate) is not recommended. For Porto Alegre, Florianópolis and Curitiba, the models with IGU resulted in energy consumption between $2.1 \%$ and $11.0 \%$ higher than models with SGUL. Campo Grande showed an oscillation among the scenarios, but with differences of energy saving between types of glass close to zero. The northernmost region of Brazil, with latitudes below $20^{\circ}$ approximately, the use of insulated glass demonstrates a certain advantage, although the expected annual energy savings achieved at a maximum of $3.6 \%$.

This study covered nine Brazilian cities, highlighting the climate differences in the same country that strongly influence the thermal performance of the building. This extends the discussion about the effectiveness of the use of IGUs as an energy efficiency strategy for office buildings in Brazil. However, this study is limited to energy consumption only. In future works, it is necessary to discuss improvements in thermal comfort, especially in areas near the windows, and the reduction in the cooling peak loads.

It should be noted that the conclusions apply only to the model of office buildings simulated here, with an open plan, lack of external shading and no influence from the building surroundings.

\section{Acknowledgement}

This study was financed in part by the Coordenação de Aperfeiçoamento de Pessoal de Nível Superior - Brasil (CAPES) - Finance Code 001

\section{Nomenclature}

$\mathrm{CC}_{\text {dif }}$ Percentage difference of cooling consumption between models that applied IGU and SGU

$\mathrm{CC}_{\mathrm{IGU}}$ Cooling consumption of model that applied IGU

CC SGUL Cooling consumption of model that applied SGU

IGU Insulated Glass Unit

HVAC Heating, Ventilating and Air Conditioning, i.e. Climate System.

PTHP Packaged Terminal Heat Pump

$\mathrm{SGU}_{\mathrm{L}}$ Laminated Single-pane Glass Unit

SHGC Solar Heat Gain Coefficient

U value Thermal Transmittance

WWR Window-to-Wall-Ratio

\section{References}

American Society ff Heating, Refrigerating And AirConditioning Engineers (2007). Energy Standard for Building Except Low-Rise Residential Buildings. (ANSI/ASHRAE/IESNA STANDARD 90.1). 
Associação Brasileira de Normas Técnicas (2008). Instalações de ar-condicionado - Sistemas centrais e unitários. Parte 1: Projetos das instalações (ABNT NBR 16.401-1).

Atzeri, A. M. et al. (2016). Comfort metrics for an integrated evaluation of buildings performance. Energy and Buildings 127, 411-424.

Besen, P., westphal, F. S. (2014). Fachadas de vidro no brasil: um estudo comparativo de viabilidade econômica. Proceedings from ENTAC2014: Encontro Nacional De Tecnologia Do Ambiente Construido. Maceió (BR), 12-14 november 2014.

Carvalho, M. M. Q., Rovere, E. L., Gonçalves, A. C. M. (2010). Analysis of variables that influence electric energy consumption in commercial buildings in Brazil. Renewable and Sustainable Energy Reviews 14 (9), 3199-3205.

Huang, Y.; Niu, J.-L.; Chung, T.-M. (2014). Comprehensive analysis on thermal and daylighting performance of glazing and shading designs on office building envelope in cooling-dominant climates. Applied Energy 134, 215-228.

Instituto Nacional de Metrologia, Qualidade e Tecnologia (2013). Requisitos técnicos da qualidade para o nível de eficiência energética de edificios comerciais, de serviços e públicos (RTQ-C).

International Standard (2005). Ergonomics of the thermal environment - Analytical determination and interpretation of thermal comfort using calculation of the PMV and PPD indices and local thermal comfort criteria (ISO 7730).

Jaber, S., Ajib, S. Thermal and economic windows design for different climate zones. Energy and Buildings 43 (11), 3208-3215.
Lawrence Berkeley National Laboratory (2016). WINDOW 7.4. Available in: https://windows.lbl.gov/software/window/window.ht $\mathrm{ml}$

Lam, J. C., Hui, S. C. M. (1995). Sensitivity Analysis of Energy Performance of Office Buildings. Building And Environment 31 (1), 27-39.

Lee, J. W. et al. (2013). Optimization of building window system in Asian regions by analyzing solar heat gain and daylighting elements. Renewable Energy 50, 522531.

Li, D. H.W, Lam, J. C. (2000). Solar heat gain factors and the implications to building designs in subtropical regions. Energy and Buildings 32 (1), 47-55.

Ministério de Minas e Energia (2016). Balanço Energético Nacional 2016: ano base 2015 (BEN 2016).

Ochoa, C. E. et al. (2012). Considerations on design optimization criteria for windows providing low energy consumption and high visual comfort. Applied Energy 95, p.238-245.

Pereira, E., Martins, F. R., Abreu, S. L., Ruther, R. (2006). Atlas Brasileiro de Energia Solar. INPE. ISBN 97885-17-00030-0.

Pillar, V. de P. (1995). Clima e vegetação. UFRGS, Departamento de Botânica. Porto Alegre (BR).

Poirazis, H., Blomsterberg, Å., Wall, M. (2008). Energy simulations for glazed office buildings in Sweden. Energy and Buildings 40 (7), 1161-1170.

Stegou-Sagia, A. et al. (2007).The impact of glazing on energy consumption and comfort. Energy Conversion and Management 48 (11), 2844-2852.

U.S. Department of Energy - DOE (2019). Weather Data. Available in: <https://energyplus.net/weather>. 